Article

\title{
Nursing as a Sustainability Factor of the Health System during the COVID-19 Pandemic: A Qualitative Study
}

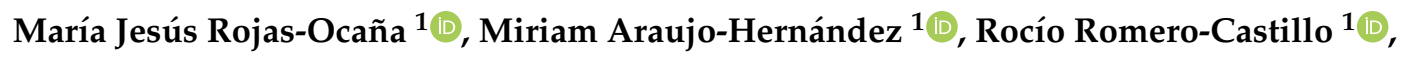 \\ Silvia San Román-Mata ${ }^{2} * *$ and E. Begoña García-Navarro ${ }^{1}$ \\ 1 Nursing Department, University of Huelva, 21071 Huelva, Spain; mariaj.rojas@denf.uhu.es (M.J.R.-O.); \\ miriam.araujo@denf.uhu.es (M.A.-H.); rocio.romero@denf.uhu.es (R.R.-C.); \\ bego.garcia@denf.uhu.es (E.B.G.-N.) \\ 2 Nursing Department, University of Granada, 18071 Granada, Spain \\ * Correspondence: silviasanroman@ugr.es
}

Received: 22 July 2020; Accepted: 16 September 2020; Published: 1 October 2020

check for updates

\begin{abstract}
Earlier this year, Spain took center stage in the emerging health crisis due to the SARS-CoV-2 pandemic. On 14 March 2020, a state of alarm was declared to manage this health crisis. The contribution of nursing professionals to sustainability of the system during this health crisis has been vital, not only in specialized care but, in a more understated way, in primary care. The objective of the present study was to describe the perceptions and lived experiences of primary care nurses during the COVID-19 health emergency. A qualitative study taking a phenomenological approach was carried out, triangulating data collected through non-participant observations, eight in-depth interviews, and two discussion groups with community nurses and case managers. A total sample of 20 key informants was obtained during the month of May, 2020. The key informants expressed strong positive perceptions of the recognition received from service users and satisfaction when acknowledging that they have been an important source of emotional support. Informants identify the importance of their work in sustaining the system, particularly outlining team cohesion and communication, whilst also evaluating the empowering position in which service users and society itself has put them.
\end{abstract}

Keywords: nursing identity; Covid-19; health system; sustainability; pandemic

\section{Introduction}

The current Spanish public health system has its roots in the middle of the last century and is inspired by European continental models of social security, however, unlike these models, it employs an extensive network of internally governed centers and organizations of an ambulatory and hospital nature [1]. Spanish Law regarding general health services (1986) established a national health system made up of 17 regional health services. The Spanish health system is mainly financed by taxes and offers free universal health coverage, including primary, specialized, and hospital care [2]. This health system has endured different economic crises. These have revealed its ability to sustain an indispensable and safe collective network, greatly helping to cushion the effects of poverty in Spain [3].

Earlier this year, Spain took center stage in the emerging health crisis due to the SARS-CoV-2 pandemic. On 14 March 2020, a state of alarm was declared to manage this health crisis. At this point, the World Health Organization had already updated the state of public health emergency to an international pandemic [4]. Latest figures place Belgium, the United Kingdom, and Spain as the countries with the most coronavirus deaths after accounting for number of inhabitants. Of these, 
Spain is the third hardest hit country by this pandemic. Isolation has been recognized as the most effective form of early intervention to prevent the spread of the virus, despite the possibility of bringing about a possible subsequent economic crisis that will have serious consequences [5]. Retail stores were closed to the public with the exception of food establishments and those selling basic necessities. Hotel and restaurant services were also suspended, as were popular events and festivals [4]. Countries debate between prioritizing the health of the population and keeping the economic wheels in motion. Another consideration is maintaining the sustainability of the health system so that it is able to respond to possible pandemic outbreaks and plan effective targeted actions.

The contribution of nursing professionals throughout this pandemic has been vital for combatting the virus, not only in specialized care but, in a more understated way, in primary care [6]. Health centers have been completely converted, overnight, into community spaces which are geographically and strategically well located to conduct screening and target cases. This has meant a total change from the traditional healthcare method towards a remote model. Greenhalgh, Koh, and Car [7] describe how the majority of COVID-19 cases can be approached remotely, not only by phone, but also through video consultation. This provides better visual cues which add to the assessment of clinical situation and health status. Nursing professionals are highly competent when it comes to communication and dialogue [8]. The profession itself favors health promotion and prevention, alongside individual and community development. Thus, the situation faced by the Spanish system could be potentially apocalyptic, whilst the identity of nurses could be crucial in holding back the tide of future pandemics, representing a critical sustainability factor of the health system.

The International Council of Nursing and the World Health Organization has also raised the identity of nurses as a priority within the system. To this end, the international Nursing Now campaign established 2020 as the international year of nursing [9]. This initiative aims to coordinate the implementation of activities worldwide, changing the vision, influence, and leadership of nursing in 2020. Main objectives set out by the campaign include emphasizing professional development, participation of nurses in global health policies, and incorporating nurses as figureheads in leadership positions. An example of the latter was seen during the pandemic, with a professional nurse being integrated into the technical advisory cabinet of the government.

As a consequence of this pandemic, the image of nursing professionals has been revitalized in a way never seen before [10]. The promotion, acknowledgement, and recognition of the work of nursing professionals on social media has been and continues to be highly relevant. This is novel, but it is largely unknown how the protagonists themselves perceive these actions, whether the group takes notice of this recognition, and whether the identity of nursing has truly been modified.

In the current literature, few studies report the experiences of professionals who have lived this situation on the front line and the meaning attributed to them [11]. This is probably due to the fact that this remains a relatively new phenomenon. Professional identity is identified as "awareness of the role and functions that one performs or is expected to perform in a social context, as a member of a particular profession" [12].

The above encapsulates the importance of the results that will be reported in the present article. This work is important for exploring the professional identity of nurses during the pandemic, as well as the influence of the experiences lived whilst exercising their daily duties. This will be achieved by describing the professional identity of nurses and community care nurses faced with the COVID-19 health crisis regarding self-concept, recognition, and satisfaction. It will identify the needs, difficulties, and challenges posed by the health crisis and serve to align the objectives of managers and health professionals to generate a more sustainable system [7,13,14].

Objectives:

Explore the professional identity of nurses faced with a health crisis.

- Study the non-conceptualized lived experiences of nursing professionals and the meaning attributed to these experiences. 
- Identify the perceptions of nursing professionals regarding the degree of recognition received from service users in the community setting.

\section{Materials and Methods}

\subsection{Study Design}

A qualitative design and phenomenological approach was followed through content analysis as described by Taylor and Bodgan [15].

\subsection{Setting and Participants}

The present study aimed to understand the meaning of the experiences lived during the pandemic and how these affect professional identity. Analysis is conducted of utterances of community and liaison nurses from 7 primary care health centers of Huelva, Andalusia. The competencies of both nurses are defined in Spain as follows: A community nurse (hereafter EC) is responsible for addressing the health problems of the family, takes responsibility for the care plan, and must provide the necessary resources and services available in the health center. On the other hand, a nurse case manager (hereafter EGC) is responsible for the management of cases, and for ensuring an integrated and continuous intervention between the professionals, sectors, and levels of care involved through the coordination and optimal use of social resources (Figure 1).

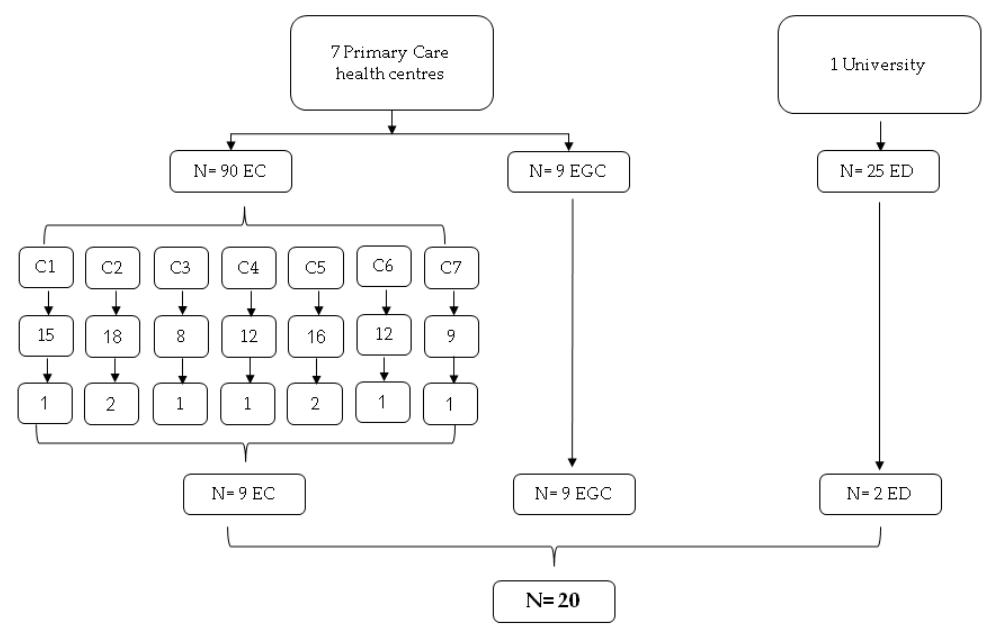

Figure 1. Participant flow diagram.

Intentional sampling was carried out in May this year to achieve this objective. The sample size was progressively determined during the course of the investigation until information saturation was reached. Inclusion criteria considered only professionals (EC and EGC) with a minimum of 2 years professional experience in the primary care environment. Further, to be included, nurses had to have been active during the pandemic period and provide verbal and written consent to participate voluntarily in the research. Sociodemographic and professional variables were taken into account for each participant.

In order to recruit key informants, an EGC linked to our university served as a liaison with potential candidates. We aimed to select individuals with experience in the object of study. In turn, because of the increased difficulty of access to potential participants arising from the state of alarm, we resorted to the "snowball" technique. In this sense, participants were reached through a network of personal relationships with the interviewees. Participants were contacted by telephone and, after verifying that they met the selection criteria and agreed to participate voluntarily as informants, were summoned for an interview, with this main question: What is your opinion regarding the professional identity of nurses and their role with users and family members in the home environment? In order to obtain 
sufficient variability and provide greater depth to the discourse analysis, a number of structural variables were taken into account for the choice of participants. Specifically, professionals were of different ages, with different years of professional experience and belonged to primary care centers in different geographical areas. The sample consisted of 9 EGC nurses, 9 EC nurses, and 2 nurse teachers (ED), distributed between interviews and discussion groups.

Study period: Fieldwork was carried out between 1 and 20 May 2020.

\subsection{Data Collection}

Given the exceptional status affecting in-person meetings during the completion of fieldwork making it impossible for researchers and participants to meet, interviews were conducted through a remote audio and video service. Researchers and participants connecting via the Zoom program, with this being recorded in full from the moment the interviewee gave their consent for this to occur. Two team members participated in the interviews with the aim of minimizing bias resulting from not having physical contact between actors. This was to mitigate the potential loss of nonverbal expressions, which may be meaningful in analysis.

One investigator proceeded to conduct the interview while the other took over the technical aspects and took fieldnotes. 8 individual interviews were conducted (4 EGC and 4EC). Further, two discussion groups took place with 6 informants in each. Discussion groups introduced the nurse teacher expert on identity and social representations. None of the researchers involved in data collection maintained industrial relations with participants.

Research team members moderated discussion groups and the development of the interviews, which were based on a number of guiding questions (Annex 1 in Supplementary Materials). The aim of these questions was to uncover relevant topics, as described in the model of Taylor and Bodgan [15]. This model proposes an approach based on three moments (discovery, coding, and relativization) which contain up to about twenty actions that seek "the development of an in-depth understanding of the scenarios or people being studied". The interviews lasted approximately $30 \mathrm{~min}$. This analysis allowed us to investigate those aspects most relevant to the elaboration of the script used for focus groups (Annex 1 in Supplementary Materials). A nurse with a teacher profile and researcher in social representations had a fundamental role in the development of focus groups, which lasted between 45 and $60 \mathrm{~min}$.

To achieve the greatest possible objectivity, biases were reduced through the use of open and non-leading questions. Likewise, to avoid subjectivity, each researcher compared their observations with those of the rest of the research team in order to contrast and debate interpretations. Finally, the most appropriate methods for the proposed study were chosen and adapted.

\subsection{Data Analysis}

At this stage, a deductive coding process was followed based on information obtained and classified into dimensions, categories, and subcategories. In turn, participants were attributed with an alphanumeric code that served to record data and develop categories and subcategories. Codes were understood as the minimum units of analysis, and were composed of several lines or phrases representing a central idea drawn from the interviews. For the discourse analysis, a preliminary manual categorization was carried out and coded using the Atlas.ti computer program. 8.0 (Scientific Software Development GmbH, Berlin, Germany). Data triangulation was carried out, using various techniques (non-participant observation, interviews, and discussion groups) in order to grant greater validity and reliability to the obtained data.

During data collection, informed consent was received from informants, and confidentiality and anonymity were maintained throughout. Prior to study start, participants were informed about the study objectives, and the bioethical principles of the Helsinki declaration were respected [16]. Likewise, data obtained from the various discourses comply with current regulations regarding the protection of personal data [17]. The code of ethical approval is IdentEnf-Dibujocovid19 from CEI of Huelva. 


\section{Results}

The study population was made up of a total of 20 key informants, 9 case management nurses (EGC), 9 community nurses (EC), and 2 teaching nurses $(E D)$, with a mean age of 48.2 years $(S D=5.86)$ and mean professional experience in primary health care of 14.17 years $(\mathrm{SD}=8.97)$. The sociodemographic and professional characteristics of the population are summarized in Table 1.

Categories drawn from discourse analysis

During the non-participant observation, interviews, and discussion groups, different categories underlying the professional identity of nurses emerged. Such themes arise following reflection on the way in which the study population thinks, talks about, and intervenes on a day-to-day basis in relation to the well-being and health of individuals and groups. Three categories were used for this analysis:

- Self-concept: Understood as the concept of oneself as a nursing professional.

- $\quad$ Recognition: Understood as positive declarations of service users regarding the work performed by nurses.

- $\quad$ Satisfaction or dissatisfaction with work at home.

The analysis of the discourses provided subcategories, which allowed us to give meaning to our analysis. The following table lists the techniques used and the categories and subcategories underlying these techniques (Table 2). Later, Tables 3-5 shows emerging results relating to the self-concept category, to the recognition category and satisfaction category respectively. 
Table 1. Sociodemographic characteristics of participants.

\begin{tabular}{|c|c|c|c|c|c|c|c|}
\hline Participant & Work Area & Age & Work Experience (Years) & Sex & Communication Training & Training in Clinical Interviews & Participation \\
\hline Participant 1 & Community nurses 1 & 46 & 6 & Female & No & Basic & Interview \\
\hline Participant 2 & Community nurses 2 & 45 & 18 & Male & No & No & Interview \\
\hline Participant 3 & Community nurses 3 & 37 & 3 & Male & Basic & Basic & Interview \\
\hline Participant 4 & Community nurses 4 & 56 & 2 & Female & No & Basic & Interview \\
\hline Participant 5 & Community nurses 5 & 50 & 7 & Female & No & No & Focus group 1 \\
\hline Participant 6 & Community nurses 6 & 42 & 4 & Female & Basic & No & Focus group 1 \\
\hline Participant 7 & Community nurses 7 & 48 & 2 & Female & No & No & Focus group 1 \\
\hline Participant 8 & Community nurses 8 & 46 & 16 & Female & No & No & Focus group 2 \\
\hline Participant 9 & Community nurses 9 & 45 & 9 & Female & Basic & Basic & Focus group 2 \\
\hline Participant 10 & Case managers 1 & 51 & 17 & Female & Advanced & Advanced & Interview \\
\hline Participant 11 & Case managers 2 & 52 & 24 & Female & Basic & Advanced & Interview \\
\hline Participant 12 & Case managers 3 & 55 & 27 & Female & Basic & Basic & Interview \\
\hline Participant 13 & Case managers 4 & 45 & 11 & Male & No & Basic & Interview \\
\hline Participant 14 & Case managers 5 & 56 & 25 & Female & Basic & Basic & Focus group 1 \\
\hline Participant 15 & Case managers 6 & 51 & 24 & Female & Basic & Basic & Focus group 1 \\
\hline Participant 16 & Case managers 7 & 49 & 27 & Female & Basic & Basic & Focus group 2 \\
\hline Participant 17 & Case managers 8 & 47 & 16 & Male & Advanced & Basic & Focus group 2 \\
\hline Participant 18 & Case managers 9 & 49 & 17 & Female & Basic & Basic & Focus group 2 \\
\hline Participant 19 & Nurse teaching 1 & 36 & 7 & Female & Advanced & Advanced & Focus group 1 \\
\hline Participant 20 & Nurse teaching 1 & 58 & 4 & Male & Advanced & Basic & Focus group 2 \\
\hline
\end{tabular}


Table 2. Categories and subcategories to emerge from the study according different techniques.

\begin{tabular}{|c|c|c|c|c|c|}
\hline Dimension & Categories & Subcategories & $\begin{array}{l}\text { Non-Participant } \\
\text { Observation }\end{array}$ & Interviews & $\begin{array}{l}\text { Discussion } \\
\text { Groups }\end{array}$ \\
\hline \multirow{10}{*}{$\begin{array}{l}\text { Professional } \\
\text { identity }\end{array}$} & \multirow{3}{*}{ Self-concept } & $\begin{array}{l}\text { Nurses as a resource, } \\
\text { guide, and source of } \\
\text { emotional support }\end{array}$ & * & * & * \\
\hline & & Professional independence & * & * & \\
\hline & & Professional self-esteem & * & * & \\
\hline & \multirow{3}{*}{ Recognition } & Contribution to learning & * & * & \\
\hline & & $\begin{array}{l}\text { Coordination with } \\
\text { professionals }\end{array}$ & * & & * \\
\hline & & $\begin{array}{l}\text { Patient-family emotional } \\
\text { support and back-stop }\end{array}$ & * & * & * \\
\hline & \multirow{4}{*}{ Satisfaction } & Comfort & * & & * \\
\hline & & Emotional relief & * & & * \\
\hline & & Humane & * & * & * \\
\hline & & Team communication & * & & * \\
\hline
\end{tabular}

* Categories and subcategories to emerge from the study.

Table 3. Emerging results relating to the self-concept category.

\begin{tabular}{|c|c|c|}
\hline Subcategory & Nurse Case Manager & Community Nurse \\
\hline \multirow[t]{2}{*}{$\begin{array}{l}\text { Nurses as a } \\
\text { resource, guide, } \\
\text { and emotional } \\
\text { support }\end{array}$} & $\begin{array}{l}\text { "Educational interventions are a bit } \\
\text { longer. Well, more formal to say the } \\
\text { least. As for whether we look at } \\
\text { whether they are important or not, } \\
\text { I already believe that they are, in } \\
\text { terms of that patient education is in a } \\
\text { crisis situation like the one we have } \\
\text { experienced, where everything has } \\
\text { been fear and uncertainty. As for } \\
\text { dealing with the patient, } \\
\text { understanding, fundamentally caring, } \\
\text { to solve unforeseen situations that } \\
\text { may happen, to manage somewhat } \\
\text { independently the environment at a } \\
\text { given moment, they can also serve as } \\
\text { self-help, to express themselves, } \\
\text { to work "(GC1, segment 9-9). }\end{array}$ & $\begin{array}{l}\text { "Furthermore, I believe that we have been born to } \\
\text { help them, both the liaison nurse and the home } \\
\text { nurse, were born so that they continue taking } \\
\text { care of themselves, because there is no institution } \\
\text { possible right now, right now, that can maintain } \\
\text { the volume of population consultations, } \\
\text { from there we start" (EC3, segment 91-91). }\end{array}$ \\
\hline & $\begin{array}{l}\text { "Nurses do more than we think" } \\
\text { (GC1, segment 24-24). }\end{array}$ & $\begin{array}{l}\text { "I think that the fact that a patient has a } \\
\text { professional intervention to guide them, the fact } \\
\text { that they know that they have a professional, } \\
\text { a nurse, who is going to be there, what we have } \\
\text { said before, they must interact with something } \\
\text { whilst the care process lasts as long as it lasts. } \\
\text { Who is accompanying you in that process? } \\
\text { Who can consult the new symptoms every day to } \\
\text { help you make whatever decision, to support } \\
\text { you? I think that makes you see that if you don't } \\
\text { do this they are alone. And I think it makes them } \\
\text { say: I am going to try to do better, because at the } \\
\text { same time, you want it, we are training them, } \\
\text { we are informing them" (EC1, segment 92-92). }\end{array}$ \\
\hline
\end{tabular}


Table 3. Cont.

\begin{tabular}{|c|c|c|}
\hline Subcategory & Nurse Case Manager & Community Nurse \\
\hline & & $\begin{array}{l}\text { "Most of the things I decide and also my doctor } \\
\text { gives me that space" (EC2, segment 58-58). }\end{array}$ \\
\hline $\begin{array}{l}\text { Professional } \\
\text { independence }\end{array}$ & $\begin{array}{l}\text { "I think that with this crisis situation, } \\
\text { nurses have become empowered at a } \\
\text { social, institutional and institutional } \\
\text { level" GC1 (segment 31-31). }\end{array}$ & $\begin{array}{l}\text { "Patients know that we solve problems for them, } \\
\text { they know about our individual competences, } \\
\text { they know what issues the nursing staff have, } \\
\text { now it is not like before when if they did not } \\
\text { bring you a P10 from the doctor, we did nothing, } \\
\text { so the truth is that much has changed, a lot. } \\
\text { Primary care has changed a lot and during this } \\
\text { crisis we have been even more autonomous, } \\
\text { where possible" (EC3, segment 58-58). }\end{array}$ \\
\hline \multirow[b]{2}{*}{$\begin{array}{l}\text { Professional } \\
\text { self-esteem }\end{array}$} & & $\begin{array}{l}\text { "The truth is that in living this situation, I have } \\
\text { realized the importance of our work with the } \\
\text { patient and the family" (EC4, segment 23-23). }\end{array}$ \\
\hline & & $\begin{array}{l}\text { "Sometimes we are so involved in the daily } \\
\text { dynamics of cures, visits, consultations, papers, } \\
\text { that we are not aware that we are the cornerstone } \\
\text { of our centers and the health system. We are the } \\
\text { group of professionals who have been in the most } \\
\text { contact with those affected by COVID, both in } \\
\text { our community environment and in the case of } \\
\text { our colleagues in hospitals, and all the words of } \\
\text { the patients and relatives have been warm and } \\
\text { grateful. I am very happy with the work } \\
\text { performed" (EC6, segment 13-13). }\end{array}$ \\
\hline
\end{tabular}

Recognition. Informants were asked in the interviews whether nursing work is recognized by service users independent of whether this work is recognized by the system itself. Outcomes were again seen to be highly positive. According to participating nurses, almost all service users recognize their work and display high levels of gratitude. The role played by service users' opinions, perceptions, and judgments made in relation to the service they received are key when it comes to defining quality making evaluation of this aspect essential for providing adequate healthcare.

Table 4. Emerging results relating to the recognition category.

Contribution to learning

Coordination with professionals
"At the moment that a patient with signs of COVID who lives alone is detected, they are put into contact with the social worker to activate the necessary resources and health assets that are in the area and that are relevant at that moment" GC6 (sec 52-52).
"If you ask people you have been caring for, even when rushed or directing towards those with learning needs, I am convinced that a nurse will be mentioned to you. You ask my mother and she give you names of two or three nurses who have taught, guided and accompanied her in this confinement." (EC5 2, segment 116-116).

“Because before you were waiting for rehabilitation appointments for two months, they are no longer moving, the rehabilitator, why am I going to give you a walker, you stay in bed, you ulcerate and you die, so that is also not helping too much, I don't know what the intervention would be called" (EC6, segment 35-35). 
Table 4. Cont.

"Interdisciplinary work and socio-sanitary coordination are of vital importance for solving different patient and family problems more quickly and effectively than a nurse alone would be able to do. That is what has saved us to get out of this crisis" GC5, (sec 31-31).

Contribution to learning
"If you ask people you have been caring for, even when rushed or directing towards those with learning needs, I am convinced that a nurse will be mentioned to you. You ask my mother and she give you names of two or three nurses who have taught, guided and accompanied her in this confinement." (EC5 2, segment 116-116).

"They told us that they were "hooked" to our weekly calls, that after this intervention they felt better and that knowing that we were there, at the other end of the phone, conveyed security" (EC10 1, segment 35-35).

motional support

We contribute, I believe to well-being.

Because they also allow us to do so, before they had to make an appointment with the nurse but this situation has allowed us and enabled us to be in permanent telephone contact or even by video calls with the patient and their family, they are constantly calling me" (GC7, segment 93-93).
"They have thanked me many times for listening to them" (EC9, segment 80-80).

Satisfaction. This category seeks to express nurse satisfaction or lack of satisfaction in their work with patients being treated at home. In all the retrieved segments of this category, the well-being that nurses feel whilst carrying out their work is shown with feelings of satisfaction particularly emerging in response to improvements in patients' conditions. This category is summarized by nurse perceptions of finding comfort through their work (Table 5).

Table 5. Emerging results relating to the satisfaction category.

Comforting

Emotional relief

\footnotetext{
"They have a number to call, apart from that the fact that they get a response from the health service and everything, but they have the nurse a physical person who knows them and who knows that they are not only going to post a message, but perhaps it is to tell you: I'm fed up! Give three screams and hang up. I tell them that if they feel like screaming I do to, if you need to let it out, call me and I will answer and they shout at me and great and tomorrow if you need it again too"(GC6, segment 93-93).
}

"Just because of hearing that, after your words of encouragement, that nothing will happen, that just by being calm at home taking your medication and without being in contact with anyone, this situation will happen and we will return to normal, they say they trust us. The sensation you feel is from a job well done and I am comforted to know that" (EC8 2, segment 61-61). 
Table 5. Cont.

\begin{tabular}{|c|c|c|}
\hline Comforting & & $\begin{array}{l}\text { "Just because of hearing that, after your } \\
\text { words of encouragement, that nothing will } \\
\text { happen, that just by being calm at home } \\
\text { taking your medication and without being } \\
\text { in contact with anyone, this situation will } \\
\text { happen and we will return to normal, } \\
\text { they say they trust us. The sensation you } \\
\text { feel is from a job well done and I am } \\
\text { comforted to know that" (EC8 2, } \\
\text { segment 61-61). }\end{array}$ \\
\hline Humanely & & $\begin{array}{l}\text { "They have a number to call, apart from that } \\
\text { the fact that they get a response from the } \\
\text { health service and everything, but they have } \\
\text { the nurse a physical person who knows } \\
\text { them and who knows that they are not only } \\
\text { going to post a message, but perhaps it is to } \\
\text { tell you: I'm fed up! Give three screams and } \\
\text { hang up. I tell them that if they feel like } \\
\text { screaming I do to, if you need to let it out, } \\
\text { call me and I will answer and they shout at } \\
\text { me and great and tomorrow if you need it } \\
\text { again too"(GC6, segment 93-93). }\end{array}$ \\
\hline \multirow[t]{2}{*}{$\begin{array}{c}\text { Team } \\
\text { communication }\end{array}$} & \multirow{2}{*}{$\begin{array}{l}\text { "This health crisis, it has led us to } \\
\text { reinvent ourselves, given us the chance } \\
\text { to grow personally and professionally } \\
\text { despite all of the hard work and the } \\
\text { pain"GC7(seg 51-51) }\end{array}$} & $\begin{array}{l}\text { "Every time we had to attend a patient in } \\
\text { person with suspicious symptoms, } \\
\text { the following days everything was fear } \\
\text { until the results came. Fear for yourself and } \\
\text { especially for those around you, for our } \\
\text { families" EC6 ( } \mathrm{sec} 26-26) \text {. }\end{array}$ \\
\hline & & $\begin{array}{l}\text { "It was all chaos, we did not know what } \\
\text { regulations to attend to, constant changes, } \\
\text { nervousness, not knowing if you were } \\
\text { doing things right. But over time and } \\
\text { seeing that all of our colleagues were the } \\
\text { same, we have learned to support each } \\
\text { other." EC7 (sec 14-14) }\end{array}$ \\
\hline
\end{tabular}

Self-concept. All fragments emanating from this category were seen to have positive connotation in that nurses, despite their excessive work load, number of patients to attend, paperwork to complete, etc., know their patients and perceive duties are performed appropriately, with this serving largely as a support factor (Tables 3 and 4).

\section{Discussion}

The results obtained from the examined population present a profile that reflects positive developments in self-concept, professional independence, and self-esteem during the health crisis which were not seen prior to the pandemic. These results hint at the need to delve deeper into this line of enquiry for the improvement of professionals and, resultantly, therefore of the health system. In the same sense, several studies [18-21] have shown that the relationship between professional self-concept and the performance of workers generates job satisfaction and autonomy. A study conducted by Souza in 2013 [21] described that $99.9 \%$ of participants from their sample who performed their duties well or excellently also reported having autonomy in task completion. Further, $72.2 \%$ reported feeling professionally accomplished and competent, feelings which were largely shared by the sample used in the present study. This same study [21,22] identified that professionals' images of themselves contribute to the role of teams and that this perception could be directly related to motivation and satisfaction with coworkers. However, other studies reviewed show the opposite effect [22,23], with job 
dissatisfaction being associated with unfavorable organizational and structural conditions, impeding role performance and professional preparation itself.

Authors such as Sabanciogullari and Dogan [24] incorporated the category of self-concept into their examination of the role of nursing and the way in which this is affected by working conditions, individual characteristics, and experience in a clinical setting. This coincides with results from the present study, finding that during the initial period of the pandemic, self-concept was not perceived to be positive, however, this concept improved as communication between peers improved and fears were able to be shared. This action translates into team cohesion, improved communication, greater visibility, and professional empowerment, as expressed by service users and society. In accordance with these results, conclusions are found in relevant literature $[25,26]$ linking the organizational climate to motivation in workers. In this sense, it is important to make workers feel that they are a fundamental $\operatorname{cog}$ in the sustainability of the institution. Commitment to this may be increased through financial incentives and individual recognition, making nurses feel supported by the organization and motivated. In this way, nurses will be more responsible and able to exhibit all of their creativity to achieve the goals and objectives laid out by the system. However, given the current situation and the speed with which the pandemic developed, we suspect that the health system did not have an appropriate margin of response to be able to motivate and incentivize its professionals. Along these same lines, it is important to highlight that interprofessional coordination reflects group cohesion. This, in turn, shows that team members have shared goals and mutual respect through the use of well-timed, accurate, frequent, and resolution-focused communication $[27,28]$. In short, implementation of case management methodology can reduce the number of hospitalizations and readmissions, contribute to delaying entry into residences, improve patient satisfaction with the system, and reduce the burden placed on non-professional caregivers [29,30].

Further, in 2012, Losa and Becerro de Bengoa [31] demonstrated that professional experience leads to an increase in self-esteem, in addition to a reduction in feelings of stress, anxiety, and exhaustion. This conclusion also agrees with present results.

When referring to the concept of learning, the nurses interviewed reported that they felt like an essential part of this process during the pandemic by resolving doubts, avoiding conspiracy theories, and correcting erroneous information. This same idea was proposed in a study conducted by Mian and Khan, 2020 [32]. These authors stated that nurses redirected confusing information disseminated by unverified sources, whilst also providing basic information regarding virus reduction, transmission, and exposure. In turn, these authors highlighted the fundamental role of primary care professionals in managing, educating, and addressing user concerns. Primary care presents a key setting for the transmission of evidence-based information on virus prevention and health promotion. Along the same lines, another study [33] referred to the nurse as a figurehead in the current pandemic. Extolling this as an integral part of group working, the promotion of self-care for quality of life and protection against this new coronavirus, participation and social control, comprehensiveness of individual and collective health actions and, finally, inclusion in education.

Regarding the emotional support received by patients and families during this health crisis, present results were decisive. This is strongly linked to perceptions of self-esteem. Service users themselves also showed greater security and confidence in the nurses themselves and, therefore, in the health system. In this sense, Losa Iglesias et al. reported in their 2017 study [34] that nurses with higher self-esteem demonstrated better performance and more effective patient communication in challenging situations. This also emerged in the present study, with value being attributed to the consideration of this group as a key factor in the emotional support of the patient, holding back the tide from the system during the period of confinement. A study carried out in Bogotá [35] indicates that the magnitude of the number of people affected by this pandemic, combined with their high workload, particularly exposes nurses to work-related risks when performing tasks in the different services. Nursing care requires close contact with sick people. This carries biological risks and the likelihood of becoming infected. However, it also carries a high emotional burden due to the participation of these professional 
in complex care settings at critical times for patients and families. In turn, this situation demonstrates the commitment of professionals and the profession itself to protecting human life.

Studies such as that conducted by Keshmiri et al. [36] corroborate these findings. These authors state that the professionalism of nursing has led to patient interests being prioritized above those of the care provider. In addition to this, this group stands out for its autonomy in relation to decision-making during the COVID-19 period, highlighting this ability as an essential aspect for nurses in clinical practice [36].

According to nurses, the advantages of socio-health coordination determine numerous patient benefits, enabling them to better manage their symptoms and family needs in extreme situations such as the present one. In agreement with other studies [37], this may be due to greater access to resources. Nurses state that their profession is highly important to socio-health care due to the direct and close contact they have with patients [38], and express that community nurses play an important role in patient care, especially in-home care. Further, authors such as [39] clarify that nurses are considered to be hugely important for socio-health coordination. A reason for this is that they are the link between resources and needs of the system, coordinating healthcare resources. This was reflected in the present study through the perceptions given by informants. In the study conducted by [40], this was reflected following administration of an intervention which uncovered a decrease in the use of social and health resources targeting nursing performance. This outcome was particularly notable in the case of case managers. Some authors $[7,41,42]$ have identified approaches with regards to patient contact which may be more appropriate in current times expose formulas more appropriate to the new times for contact with patients, given that social distancing is distance necessary to avoid infection and contagions. Greenhalgh, Koh, and Car [42] outline how most COVID-19 cases can be addressed from a distance, not only by phone, but also through video consultation. The latter of these, which provides better visual cues for assessing the clinical situation and health status.

Limitations and future research directions:

- With regards to study limitations, it should be highlighted that the study was limited exclusively to the province of Huelva. Further, whilst inclusion of an interdisciplinary team was a strong point, key informants were all nurses. It would, therefore, have been more enlightening to have examined the perceptions of other health professionals, and even service users and family, on nursing work and the role of these groups in holding back the tide during the pandemic as a sustainability factor in the health system.

The present work lays the foundations for further research to consider the following aspects:

- Perceptions of all health professionals to have intervened in the COVID-19 health crisis;

- Opinions and experiences of patients and families; and

- Data from qualitative work in the other Andalusian provinces not examined here.

\section{Conclusions}

The population studied regarding self-concept, know their patients and perceive that the performance of their functions is carried out appropriately. For patients and caregivers, this collective represents a resource and source of support and accompaniment. Those working in this discipline perceived increased social assessment of their work during the pandemic. In turn, they have played a key role in social-health care. They have acting as a link between various health professionals, and they generally recognize the role of the profession in the COVID-19 health crisis.

Affective outcomes were particularly favorable with participants presenting a high degree of satisfaction in the performance of their functions during the pandemic. Human treatment, the assessment of social problems, and responding to the emotional problems of patients and families provided the main axis of the role of the nurse in home care during the health crisis. Another perceived improvement was peer communication, with this growing in the face of this adverse situation. 
Interviewees also manifested through their lived experiences that this action translated into greater team cohesion, improved communication, greater visibility, and professional empowerment.

It would be interesting to build on the momentum that this crisis has given to the nursing profession and employ socio-health coordination strategies to link all professionals involved in the home. This would enable objectives set out in the health strategy to be reached and, in this way, improve the sustainability of our health system.

Supplementary Materials: The following are available online at http://www.mdpi.com/2071-1050/12/19/8099/s1.

Author Contributions: Conceptualization, M.J.R.-O., and E.B.G.-N.; formal analysis, M.J.R.-O., and M.A.-H.; E.B.G.-N. and M.J.R.-O. Research and analysis R.R.-C., M.A.-H., and S.S.R.-M. Writing and preparation of the first draft, M.J.R.-O. and E.B.G.-N. Drafting, M.J.R.-O. and E.B.G.-N. All authors have read and agreed to the published version of the manuscript, methodology.

Funding: This research received no external funding.

Conflicts of Interest: The authors declare no conflict of interest.

\section{References}

1. Martín, J.; González, M. La sostenibilidad del Sistema Nacional de Salud en España. Ciência Saúde Coletiva 2011, 16, 2773-2782. [CrossRef]

2. Pasarín, M.; Berra, S.; González, A.; Segura, A.; Tebé, C.; García-Altés, A. Evaluación de la atención primaria: Las "Herramientas de evaluación de la atención primaria—Versión de instalación" para el sistema de salud español. Gaceta Sanit. 2013, 27, 12-18. [CrossRef]

3. Rivera, F.; Santolalla, I.; Jodra, B.; Sufrate, T. Estudio comparativo de casos sobre el papel del modelo europeo de excelencia en la sostenibilidad de las organizaciones sanitarias. Arch. Nurs. Res. 2020, 3, 71. [CrossRef]

4. Agencia Estatal Boletín Oficial del Estado. Real Decreto 463/2020 de 14 de Marzo, por el que se Declara el Estado de Alarma Para la Gestión de la Situación de Crisis Sanitaria Ocasionada por el COVID-19. BOE-A-2020-3692; Agencia Estatal Boletín Oficial del Estado: Madrid, Spain, 2020. Available online: https://www.boe.es/eli/es/rd/2020/03/14/463 (accessed on 26 June 2020).

5. Barbagelata, A.; Perna, E.; Piskorz, D.; Lorenzatti, A. Prevención del colapso del Sistema de salud en pacientes cardiovasculares con COVID-19: El rol del cardiólogo en la reducción de la sobrecarga de las unidades de cuidados intensivos con el advenimiento del frío en América del Sur. Reporte de la Federación Argentina de Cardiología. Rev. Fed. Argic. Cardiol. 2020, 49, 4-12.

6. García, V.A.; Picazo, J.; Ballesteros, M.; Pérez, L.; Moro, I.; Martínez, M.; Téllez, J.M. Para qué llaman los pacientes? Evaluación de consultas telefónicas no urgentes en Atención Primaria. Revista Clínica de Medicina de Familia 2020, 13, 7-14.

7. Brito, P. En los límites de lo cotidiano: A propósito del covid-19 en atención primaria. Revista Ene de Enfermería 2020, 14, 1-3.

8. Jiménez-Rodriguez, D.; Santillán, A.; Montoro, J.; Rodríguez, M.M.; Muñoz, F.J.; Arrogante, O. Incremento de Consultas por Video Durante el COVID-19 Pandemia: Percepciones de los Profesionales de la Salud Sobre su Implementación y Adecuación. Administración. Int. J. Environ. Res. Salud Pública 2020, 17, 5112. Available online: https://www.mdpi.com/1660-4601/17/14/5112 (accessed on 27 June 2020).

9. Stilwell, B.; Munashe, N. Nursing now. In Advanced Practice Nursing Leadership: A Global Perspective; Springer: Cham, Switzerland, 2020. [CrossRef]

10. Cacha, A. Enfermería, el reconocimiento de una profesión a través de la práctica. Conoc. Enferm. 2020, 3, 2.

11. Raurell-Torredà, M.; Martínez-Estalella, G.; Frade-Mera, M.; Carrasco, L.; Romero, E. Reflections arising from the COVID-19 pandemic. Enfermería Intensiva (English Ed.) 2020, 31, 90-93. [CrossRef]

12. Dadich, A.; Doloswala, N. What can organisational theory offer knowledge translation in healthcare? A thematic and lexical analysis. BMC Health Serv. Res. 2018, 18, 351. [CrossRef]

13. Cía, N.M.; Pérez, M.P.; Heras-Mosteiro, J.; Ávila, G.G.; Díaz-Olalla, J.M.; Aguilar, J.L. Encuentros y desencuentros entre salud comunitaria y sustema sanitario español. Informe SESPAS 2018. Gac. Sanit. 2018, 32, 17-21. [CrossRef]

14. Rivera, F.; Santolalla, I.; Ibañez, D.; Jodra, B. Metodología para el análisis de la sostenibilidad de las organizaciones sanitarias. Index de Enfermería 2018, 27, 225-229. 
15. Taylor, S.J.; Bogdan, R. Introducción a Los Métdos Cualitativos de la Investigación; Paidós: Barcelona, Spain, 1990.

16. Mundial, A.M. Declaración de Helsinki de la AMM. In Principios Éticos Para Las Investigaciones Médicas en Seres Humanos; World Medical Association, Inc.: Geneva, Switzerland, 2019.

17. Orgánica, L. de 5 de diciembre, de Protección de Datos Personales y garantía de los derechos digitales. Boletín Oficial del Estado 2018, 294, 119788.

18. Kangasniemi, M.; Pakkanen, P.; Korhonen, A. Professional ethics in nursing: An integrative review. J. Adv. Nurs. 2015, 71, 1744-1757. [CrossRef]

19. Puggina, A.C.; Cavalheiro, A.C.; Trentino, J.P.; Castro, P.; Silva, M.J. Relação entre necessidade de adornos com satisfação com imagem corporal e autoconceito profissional da equipe de enfermagem. Rev. Anna Nery 2015, 19, 563-570. [CrossRef]

20. Souza, M.E.; Amaro, B.; Silva, R.R. Relação entre autoconceito profissional e desempenho da equipe de enfermagem. In Centro Universitário de Volta Redonda. I Jornada Científica de Enfermagem do UniFOA. Centro Universitário de Volta Redonda 2013, 25. [CrossRef]

21. Piña, C.N.; López, M.M.; Delgado, I.C. Caracterización del Clima Organizacional del Policlínico Universitario “Cecilio Ruiz de Zarate” de la Provincia de Cienfuegos. Rev. Electrón. de Pedag. 2011, 3, 30-37.

22. Vera, M.; Samudio, M. Clima organizacional de enfermería en los hospitales regionales del Instituto de Previsión Social. Mem. Inst. Investig. Cienc. Salud. 2013, 11, 41-54.

23. Pérez, A. La gestión universitaria y el clima organizacional. Rev. Cubana Educ. Médica Super. 2011, 25, 164-177.

24. Sabanciogullari, S.; Dogan, S. Professional self-concept in nurses and related factors: A sample from Turkey. Int. J. Caring Sci. 2017, 10, 1676.

25. Juárez, S. Clima organizacional y satisfacción laboral. Rev. Med. Inst. Mex. Seguro 2012, 50, 307-314.

26. Segredo, A.M. Clima organizacional en la gestión del cambio para el desarrollo de la organización. Rev. Cubana Salud Pública 2013, 39, 385-393.

27. Valenziano, K.B.; Glod, S.A.; Jia, S.; Belser, A.; Brazell, B.; Dellasega, C.; Dillon, P.W. An Interprofessional Curriculum to Advance Relational Coordination and Professionalism in Early-Career Practitioners. J. Teach. Learn. Resour. 2018, 14, 10697. [CrossRef] [PubMed]

28. Segredo, A.M.; Reyes, D. Clima organizacional en salud pública. Consideraciones generales. Rev. Correo Científico Médico de Holguín 2004, 8, 3.

29. Hammar, T.; Rissanen, P.; Perälä, M.L. The cost-effectiveness of integrated home care and discarge practice for home care clients. Health Policy 2009, 92, 10-20. [CrossRef]

30. Carretero, S.; Garcés, J.; Ródenas, F. Evaluation of the home help service and its impacto $\mathrm{n}$ the informal caregiver's burden of dependent elders. Int. J. Geriatr. Psychiatry 2007, 22, 738-749. [CrossRef] [PubMed]

31. Losa, M.E.; Becerro de Bengoa, R. Prevalence of bullying at work and its association with self-esteem scores in a Spanish nurse sample. Contemp. Nurse 2012, 42, 2-10. [CrossRef]

32. Mian, A.; Khan, S. Coronavirus: The spread of misinformation. BMC Med. 2020, 18, 89. [CrossRef]

33. Costa, R.; Motta, M.; Jatobá, A.I.; Lorenzini, E.; Manfrini, G.C.; Cavalcanti, L. Enseñanza de enfermería en tiempos de covid-19: Cómo reinventarla en este contexto? Texto Contexto Enfermagem 2020, 29. [CrossRef]

34. Losa-Iglesias, M.E.; López, D.; Rodriguez, R.; Becerro, R. Relationships between social skills and self-esteem in nurses: A questionnaire study. Contemp. Nurse 2017, 53, 681-690. [CrossRef]

35. Fuentes-Bermúdez, G.P. Enfermería y COVID-19: Reconocimiento de la profesión en tiempos de adversidad. Revista Colombiana de Enfermería 2019, 19. [CrossRef]

36. Keshmiri, F.; Farahmand, S.; Bahramnezhad, F.; Nedaei, H.H. Exploring the challengues of professional identity formation in clinical education environment: A qualitative study. J. Adv. Med. Educ. Prof. 2020, 8, 42-49. [CrossRef] [PubMed]

37. Farcic, N.1.; Barac, I.; Lovric, R.; Pacaric, S.; Gvozdanovic, Z.; Ilakovac, V. The influence of self-concept on clinial decision making in nurses and nursing students: A cross-sectional study. Int. J. Environ. Res. Public Health 2020, 17, 3059. [CrossRef]

38. Jiménez, S.; Vilaplana, C. La interacción del sistema social y sanitario. Informe SESPAS 2012. Gac. Sanit. 2012, 26, 124-133. [CrossRef] [PubMed]

39. Corrales, D.; Palomo, L. La importancia de la longitudinalidad, integralidad, coordinación y continuidad de cuidados domiciliarios efectuados por enfermería. Enfermería Clínica 2014, 24, 51-58. [CrossRef] [PubMed] 
40. Carretero, L.; Gomes, N.; Borrás, A.; Rodríguez, A.; Seara, G. Integración clínica en el paciente crónico. Enfermería Clínica 2014, 24, 35-43. [CrossRef]

41. Garcés, J.; Ródenas, F. La gestión de casos como metodología para la conexión de los sistemas sanitario y social en España. Atención Primaria 2015, 47, 482-489. [CrossRef]

42. Greenhalgh, T.; Koh, G.C.H.; Car, J. Covid-19: A remote assessment in primary care. BMJ 2020, 368, m1182. Available online: https://www.ncbi.nlm.nih.-gov/pubmed/32213507 (accessed on 28 June 2020). [CrossRef]

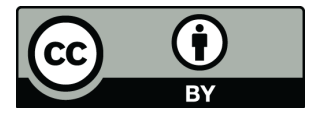

(C) 2020 by the authors. Licensee MDPI, Basel, Switzerland. This article is an open access article distributed under the terms and conditions of the Creative Commons Attribution (CC BY) license (http://creativecommons.org/licenses/by/4.0/). 